\title{
Long term Stress Management Interventions at workplace with focus on Private Banking Employees
}

\author{
Allah Baksh.S, Sulaiman.N
}

\begin{abstract}
In this competing world, every organization is competing with one another to be top in their industry. To prove the worthiness of their organization in the industry, employers automatically give more stress to the employees which lead employees to be depressed. Every industry faces stress in their work. The banking industry is not an exceptional one. The banking industry is the backbone of the country's economy. The job nature of banking staff is extremely tedious because it involves the direct client interaction with all the level. In order to overcome the problem, employers should adopt a long term stress management interventions at the workplace. The major objective of this research is to explore the impact of stress management interventions at the workplace on job motivation and to find out the reason for employee's stress at the workplace. Data were collected from 305 respondents working in different private banks in Coimbatore, Tamil Nadu, India. To collect the data, Convenience Sampling Method was used. Multiple Regression, Correlation, and Weighted Mean Average were used to analyse the collected data. Analysis reveals that some of the stress management interventions like proper job role, recognition, employee grievance handling, reducing responsibility and effective communication have an impact on job motivation. Some of the major reasons for employee's stress at workplace are work overload, poor relationships at work, reimbursement \& Benefits, etc., found to be a stress inducer in private banks. Hence it is proved that long term stress management intervention has an impact on job satisfaction among private banks employees.

Index Terms: Correlation, Multiple Regression, Private Banking, Stress Management Interventions.
\end{abstract}

\section{INTRODUCTION}

Nowadays every organization faces stress and no one can say their organization is free from stress. When an employer gives so much of work to an employee it leads to stress which automatically implies in their job which gives poor organizational performance. Susan and Steers (1981) revealed that occupational stress implies in the employee job motivation and stress can be caused by many reasons. Creating different stress management interventions will be useful for banking employees to have their work with a reduced level of stress. Job overload ends up in stressing employee and this has a negative impact on their work (Silva and Navarro, 2012). Employee's nowadays want to have a good work-life balance. Stressed employees normally cannot handle both work and life. In order to give a stress-free life, employers should concentrate on stress management among employees. Consuming the best stress management

Revised Manuscript Received on July 05, 2019.

Allah Baksh.S, Department of Sociology and Social Work, Annamalai University, Annamalai Nagar, Chidambaram, India

Sulaiman.N, Department of Business Administration, Annamalai University, Annamalai Nagar, Chidambaram, India interventions helps both employee and employer. Employees will be having less stress which influences them in higher productivity. Higher productivity helps the organization to be topper in their industry. Weiss (1983) explored that a proper stress management intervention helps in job satisfaction. The organization can be managed more effectively. During the past decade, the banking sector had underneath gone fast and hanging changes like policy changes because of liberalization and globalization due to the sudden increase in private banks, new technologies, downsizing, etc., Private banks nowadays need to cop up with the new technologies. In-order to cop up the new technologies employees are forced to keep their knowledge up-to-date which makes them stressful. Rosas (2011) examined that the level of stress normally differs from occupation to occupation. The position which an employee plays a major role is making an employee stressful. The major problems faced by employees due to stress are mental depression, irritability, and some sleeping problems. The organization should adapt techniques to reduce stress for their employees who work very hard for their organization reputations.

\section{REVIEW OF LITERATURE}

Asim Masood (2013) stated that job stress affects an employee's retention. The researcher used regression to analysis the data which was collected in the banking sector of Pakistan. Analysis reveals that work overload, role in the organization, characteristics of the job, poor relationship at works and organizational structure are some of the reason for employee's stress at the workplace.

Angweling (2014) analysed the data collected among the employees of the bank in kotak in abalu Sabah. The objective was to analysis the relationship between stress management interventions and job satisfaction. Study reveals that there is a strong relationship between stress management interventions and job satisfaction. Providing proper stress management interventions helps employees stay satisfied with their jobs.

Asfaqahmed (2013) stated that when a stress level becomes low productivity will increase. Data were collected from banking employees of Pakistan. Collected data were analysed using correlation and analysis reveals that stress level is correlated with productivity.

Ambika Ponnampalam (2013) explored that perfect stress management techniques help employees in their performance. Data were collected from eastern province's commercial bank of Ceylon. The major objective is to know the relationship between stress management interventions and

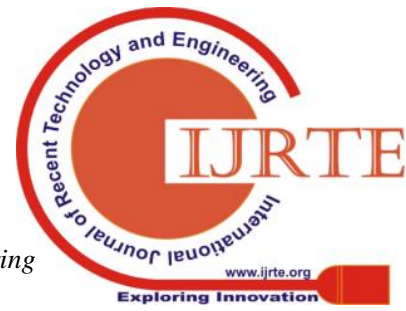


job satisfaction of an employees working in the commercial bank of Eastern province. Correlation analysis was used to analysis the data and result were found that there is a strong relationship between stress management interventions and job satisfaction.

Sharmila (2012) identified some of the stress management technique to reduce job related stress. Collected data were analysed using percentage analysis and study reveals that wellness program, flexible work arrangements, Reducing responsibility, meditation \& yoga, work in a group, recognition and continuous training are some of the stress management technique to reduce a job related stress among employees.

Ayazul Haq (2011) identified long working hours, work load, organizational culture, and work-life imbalance are some of the causes of stress for banking employees. Changing the working hours and work load helps to reduce employee's stress level.

\section{RESEARCH METHODOLOGY}

\section{A. Research Design}

The descriptive research design was adopted in this study with particular reference to Coimbatore. The sample size was 305 employees working in different banks. Convenience sampling technique was used to gather data with a structured questionnaire.

\section{B. Objectives of the Study}

- To measure the impact of stress management interventions at the workplace on job motivation.

- To analyse the relationship between stress management interventions and job satisfaction.

- To find out the reason for employee's stress at the workplace on private banking employees.

\section{Statistical Tools}

\begin{tabular}{|c|l|l|}
\hline S.no & Description of objectives & $\begin{array}{c}\text { Statistical } \\
\text { tools for } \\
\text { analysis }\end{array}$ \\
\hline 1 & $\begin{array}{l}\text { The impact of stress } \\
\text { management interventions } \\
\text { at the workplace on job } \\
\text { motivation. }\end{array}$ & $\begin{array}{l}\text { Multiple } \\
\text { Regression }\end{array}$ \\
\hline 2 & $\begin{array}{l}\text { Analysis of the relationship } \\
\text { between stress management } \\
\text { interventions and job } \\
\text { satisfaction. }\end{array}$ & Correlation \\
\hline 3 & $\begin{array}{l}\text { Reason's for employee's } \\
\text { stress at the workplace on } \\
\text { private banking employees }\end{array}$ & $\begin{array}{l}\text { Weighted } \\
\text { Average Rank }\end{array}$ \\
\hline
\end{tabular}

\section{DATA ANALYSIS}

\section{A. 4.1. Impact of Stress Management Interventions at the workplace on Job Motivation}

Table 1: Model Summary

\begin{tabular}{|c|c|c|c|c|}
\hline Model & R & $\begin{array}{c}\text { R } \\
\text { Square }\end{array}$ & $\begin{array}{c}\text { Adjusted R } \\
\text { Square }\end{array}$ & $\begin{array}{c}\text { Std. The error } \\
\text { of the Estimate }\end{array}$ \\
\hline 1 & $.959(\mathrm{a})$ & .919 & .918 & .097 \\
\hline
\end{tabular}

(a) Predictors: (Constant), Proper Job Role, Employee Grievances Handling, Continuous Training, Effective Communication, Recognition, Work in Group, Meditation \& Yoga, Reducing Responsibility, Flexible Work Arrangements, Wellness Program

From the above table $1, \mathrm{R}$ can be considered to be one measure of the quality of the prediction of the dependent variable (Job Motivation). A value of 0.959 indicates a good level of prediction. The $R^{2}$ value is 0.919 that independent variables explain $91.9 \%$ of the variability of the dependent variable (Job Motivation).

Table 2: ANOVA ${ }^{\mathbf{b}}$

\begin{tabular}{|c|c|c|c|c|c|c|}
\hline & Model & $\begin{array}{l}\text { Sum of } \\
\text { Squares }\end{array}$ & df & $\begin{array}{c}\text { Mean } \\
\text { Square }\end{array}$ & $\mathbf{F}$ & Sig. \\
\hline \multirow[t]{3}{*}{1} & Regression & 94.449 & 6 & 15.742 & 56.194 & $.000^{\mathrm{a}}$ \\
\hline & Residual & 8.285 & 298 & .028 & & \\
\hline & Total & 102.734 & 304 & & & \\
\hline
\end{tabular}

a. Predictors: (Constant), Proper Job Role, Employee Grievances Handling mechanism, Continuous Training, Effective Communication, Recognition, Work in Group, Meditation \& Yoga, Reducing Responsibility, Flexible Work Arrangements, Wellness Program

b. Dependent Variable: Job Motivation

The above table 2, shows that the Proper Job Role, Employee Grievances Handling mechanism, Continuous Training, Effective Communication, Recognition, Work in Group, Meditation \& Yoga, Reducing Responsibility, Flexible Work Arrangements, Wellness Program statistically significantly predict the Job Motivation, $F(6,298)=$ $56.194, p<.0005$ (i.e., the regression model is a good fit of the data). 
Table 3 Coefficients ${ }^{(a)}$

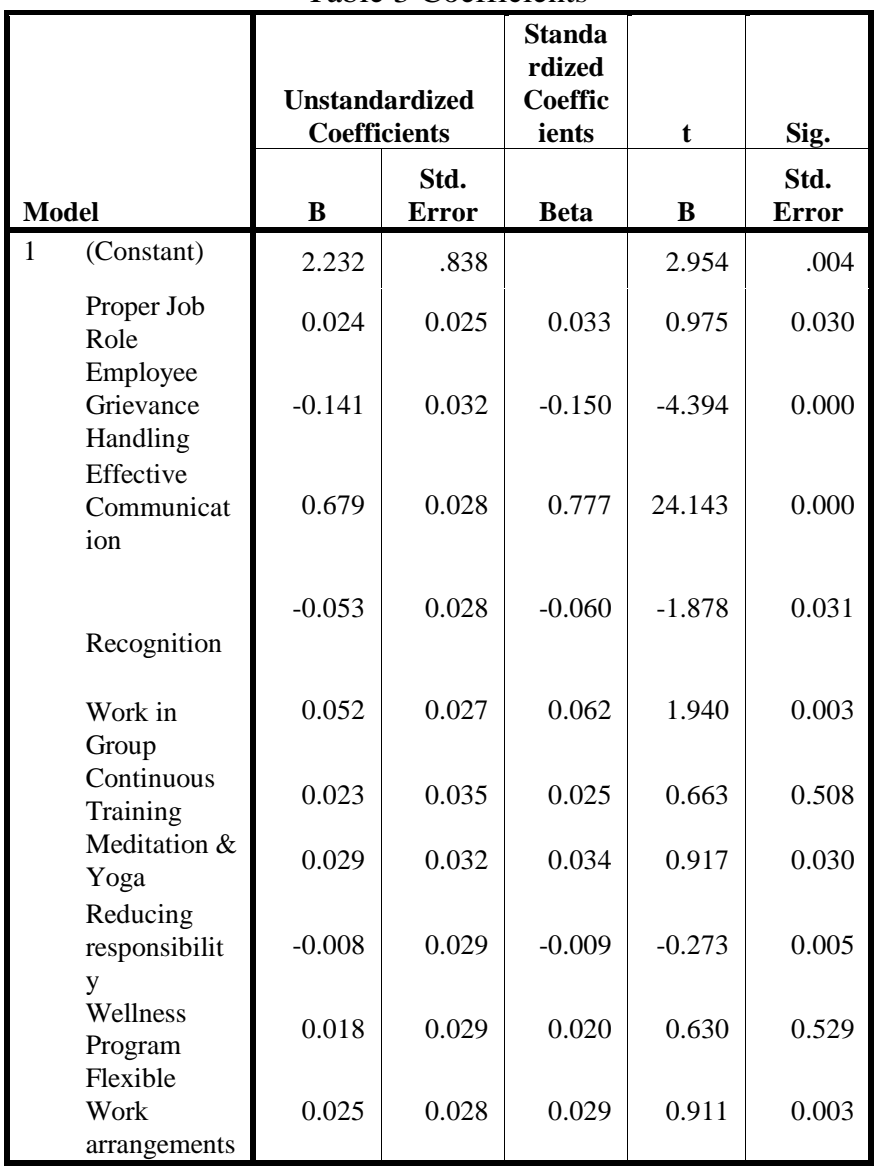

a. Dependent Variable: Job Motivation

The above table 3, explains unstandardized coefficients indicate the extent to which Job Motivation varies with a Proper Job Role, Employee Grievances Handling mechanism, Continuous Training, Effective Communication, Recognition, Work in Group, Meditation \& Yoga, Reducing Responsibility, Flexible Work Arrangements, Wellness Program is held constant.

Continuous Training \& Wellness Program's p value is greater than 0.05 .

Multiple Regression equation is:

Job Motivation $=2.323+(0.033 *$ Proper Job Role $)$ $(0.150 *$ Employee Grievance Handling) $+(0.777 *$ Effective Communication) - $(0.060 *$ Recognition $)+(0.062$ * Work in Group) + (0.034* Meditation \& Yoga $)$ - $(0.009 *$ Reducing responsibility $)+(0.029 *$ Flexible $\quad$ Work arrangements)

Proper Job Role, Employee Grievances Handling, Effective Communication, Recognition, Work in Group, Meditation \& Yoga, Reducing Responsibility, Flexible Work Arrangements significant values are $<0.05$.

B. Relationship between Stress Management Interventions and Job Motivation
Table 4

\begin{tabular}{|ll|r|r|}
\hline & & \multicolumn{1}{c|}{\begin{tabular}{c}
\multicolumn{1}{c|}{ Job } \\
Motivation
\end{tabular}} & $\begin{array}{c}\text { Stress } \\
\text { Management } \\
\text { Interventions }\end{array}$ \\
\hline $\begin{array}{llr}\text { Job } \\
\text { Motivation }\end{array}$ & $\begin{array}{l}\text { Coarson } \\
\text { Sig. (2-tailed) }\end{array}$ & 1 & $.922(* *)$ \\
& $\mathrm{N}$ & 305 & .000 \\
$\begin{array}{l}\text { Stress } \\
\text { Management }\end{array}$ & Pearson & & 305 \\
Interventions & Sorrelation & $.922(* *)$ & 1 \\
& Sig. (2-tailed) & .000 & 305 \\
\hline
\end{tabular}

** Correlation is significant at the 0.01 level (2-tailed).

From the above table 4 , it is clearly understood that the correlation between Job Motivation has a strong relationship with Stress Management Interventions. Correlation of Job Motivation and Stress Management Interventions $(r=0.922)$, based on $n=305$. There is a strong relationship between Job Motivation and Stress Management Interventions.

C. Major reasons for employee's stress at the workplace

Table 5

\begin{tabular}{|l|c|c|}
\hline Reasons for Employee's Stress & Mean & Rank \\
\hline Characteristics of the Job & 4.77 & V \\
\hline Work Overload & 4.99 & I \\
\hline Role in Organization & 4.75 & VI \\
\hline Relationships at Work & 4.95 & II \\
\hline Organizational Structure & 4.60 & VIII \\
\hline Organization Culture & 4.68 & VII \\
\hline Reimbursement \& Benefits & 4.86 & III \\
\hline Work Life Imbalance & 4.80 & IV \\
\hline
\end{tabular}

From the analysis table 5, it was found that work overload ranks first with the mean value of 4.99 , Relationships at Work ranks second with the mean value of 4.95 , Reimbursement $\&$ Benefits ranks third with the mean value of 4.86 , Work Life Imbalance ranks fourth with the mean value of 4.80 , Characteristics of the Job ranks fifth with the mean value of 4.77, Role in Organization ranks sixth with the mean value of 4.75, Organization Culture ranks seventh with the mean value of 4.68 and Organizational Structure ranks eighth with the mean value of 4.60 . 


\section{CONCLUSION}

Identifying the best stress management interventions helps in reducing the stress of an employee. Once banking sector adopts the best stress management technique, it would be useful for employers to make employees stay in an organization and have a good improvement in productivity. Job Motivation helps the employee to be more productive. Proper Job Role, Employee Grievances Handling mechanism, Effective Communication, Recognition, Work in Group, Meditation \& Yoga, Reducing Responsibility, and Flexible Work Arrangements plays a major role in reducing stress among private bank employees. It is clearly found that implementing the best stress management techniques helps stay satisfied with the jobs. Some of the stress inducer among employee's of private banks are work overload, Poor relationships at work, Reimbursement \& Benefits, Work Life Imbalance, Characteristics of the Job, Role in the organization, Organization Culture, and Organizational Structure. It's employer's duty to take care of employees who work for their organization's reputation. Making employees stress free helps an organization to have a proper reputation.

\section{REFERENCES}

[1] Susan Rhodes and Richard Steers, "A Systematic Approach to Diagnosing Employee Absenteeism”, Employee Relations, Vol. 3 Issue: 2, 1981, pp.17-22, https://doi.org/ 10.1108/eb054966,

[2] Madeline Weiss, MIS March, "Work Stress and social support, Effects of Work Stress and Social Support on Information Systems", 1983.

[3] José Humberto Ablanedo-Rosas, Randall C. Blevins, HongmanGao, Wen-Yuan Teng, Joann White, The impact of occupational stress on academic and administrative Staff, and on students: an empirical case analysis", Journal of Higher Education Policy and Management, Vol. 33, No. 5, 2011, pp. 553-564.

[4] AyazulHaq, "Occupational stress and burn out in pakistans banking sector", African journal of business management, 5 (3), 2011, pp.810-817.

[5] Sharmila, A, "A study on employees management in selected private banks in Salem", Elixir international journal, 42, 2012, pp.6555-6558.

[6] Silva J. L., Navarro V. L., "Work organization and the health of bank employees", Rev. Latino Am. Enfermagem. 20, 2012, pp.226-234. 10.1590/S0104-11692012000200003.

[7] Asfaq Ahmed, "Effect of job stress on employees job performance a study on the banking sector of Pakistan", IOSR journal of business and management, 11, 2013, pp. 61-68.

[8] Ambika Ponnampalam, "A study on the effect of stress on the performance of employees in the commercial bank of ceylon in the eastern province", European journal of business management, 1 (27), 2013, pp.87-95.

[9] Angweling, "A study on role stress and job satisfaction among bank employees in kotak in a balusabah", International journal of research in management and business studies, Volume 1 Issue 2, 2014, pp.19-23. 